Le monde te confie sa force en échange de ta confiance.

\title{
Pierre Reverdy
}

Sam Rohdie - 9781526141699

Downloaded from manchesterhive.com at $04 / 26 / 2023$ 07:10: $06 \mathrm{AM}$ 